\title{
Potensi dan Penggunaan Limbah Sagu Fermentasi sebagai Pakan Sapi di Kabupaten Kepulauan Meranti
}

\author{
(Potential and Utilization of Fermented Sago Byproduct as Cattle Feed in \\ Meranti Islands District)
}

\author{
Sisriyenni $\mathrm{D}^{1}$, Simanjuntak $\mathrm{A}^{1}$, Adelina $\mathrm{T}^{2}$ \\ ${ }^{1}$ Balai Pengkajian Teknologi Pertanian Riau, Jl. Kaharuddin Nst No. 341, Pekanbaru \\ ${ }^{2}$ Universitas Islam Sultan Syarif Kasim Riau, Jl. Raya Pekanbaru, Bangkinang, Pekanbaru \\ dwisriyenni@yahoo.co.id
}

\begin{abstract}
Utilization of waste from sago as a cattle feed for Bali bull was conducted from July-October 2016 in the Village of Darul Aman Maini District of Meranti Islands. A number of 20 head Bali bulls with average body weight $200 \mathrm{~kg}$ were grouped into 4 treatment respectively as follows: A: $100 \%$ natural grass $+0 \%$ feed fermentation + rice bran (control); B: $75 \%$ natural grass $+25 \%$ feed fermentation + rice bran; $\mathrm{C}: 50 \%$ natural grass $+50 \%$ feed fermentation + rice bran; and D: $25 \%$ natural grass $+75 \%$ feed fermentation + rice bran. Fermented completed feed material composed of a mixture of $60 \%$ chopped sago leaf midrib, $30 \%$ sago waste, $5.75 \%$ rice bran, $0.25 \%$ urea, $3 \%$ molasses and $0.1 \%$ salt, probion was added as much as $0.5 \%$ of the total feed stuffs. Daily weight gain was measured once every two weeks while feed intake recorded everyday. Treatment feed is not significant influence $(\mathrm{P}>0.05)$ to dry matter consumption and daily weight gain of Bali cattle in each treatment. Meanwhile treatment completed feed gave significant influence $(\mathrm{P}<0.01)$ to feed dry matter digestibility. The study showed that fermented sago byproduct up to $50 \%$ resulting average daily weight gain $0.58 \mathrm{~kg} /$ day and production as much 2,640,000 ton/year sago waste potential to supply 2,411 Bali cattle/year.
\end{abstract}

Key Words: Sago Waste, Feed, Average Daily Gain

\begin{abstract}
ABSTRAK
Pemanfaatan limbah sagu sebagai pakan ternak untuk sapi Bali dilakukan dari bulan JuliOktober 2016 di Desa Darul Aman Maini, Kabupaten Kepulauan Meranti. Sebanyak 20 ekor sapi Bali jantan dengan rata-rata berat badan $200 \mathrm{~kg}$ dikelompokkan ke dalam 4 perlakuan yaitu: A: $100 \%$ rumput alam $+0 \%$ pakan fermentasi + dedak (kontrol); B: $75 \%$ rumput alam $+25 \%$ pakan fermentasi + dedak; C: $50 \%$ rumput alam $+50 \%$ pakan fermentasi + dedak; dan D: $25 \%$ rumput alam $+75 \%$ pakan fermentasi + dedak. Bahan pakan komplit terfermentasi terdiri dari campuran $60 \%$ cacahan pelepah daun sagu, $30 \%$ ampas sagu, 5,75\% dedak padi, $0,25 \%$ urea, $3 \%$ molasses dan $0,1 \%$ garam, serta ditambah probion sebanyak $0,5 \%$ dari total pakan. Data pertambahan berat badan harian $(\mathrm{PBBH})$ sapi diukur satu kali per dua minggu sedangkan data konsumsi pakan diukur setiap hari. Perlakuan pakan yang diberikan tidak berpengaruh nyata $(\mathrm{P}>0,05)$ terhadap konsumsi BK dan PBBH sapi Bali pada masing-masing perlakuan. Sementara perlakuan pakan komplit memberikan pengaruh yang sangat nyata $(\mathrm{P}<0,01)$ terhadap kecernaan bahan kering $(\mathrm{KCBK})$ pakan. Kesimpulan menunjukkan bahwa pemberian limbah sagu terfermentasi hingga 50\% menghasilkan PBBH sebesar 0,58 kg/hari dan produksi sebanyak 2.640.000 ton/tahun limbah sagu mampu memenuhi kebutuhan 2.411 ekor sapi Bali/tahun.
\end{abstract}

Kata Kunci: Limbah, Sagu, Pakan, PBBH 


\section{PENDAHULUAN}

Berdasarkan data BPS Riau (2013) luas perkebunan sagu di Riau sekitar 82.713 ha dengan produksi tepung sagu 281.784 ton/tahun. Dari data tersebut diprediksi bahwa terdapat potensi daun sagu sebesar 25.360.560 tangkai atau setara 25.360 ton serta pelepah daun sagu 3.606.272 ton. Kabupaten Kepulauan Meranti memiliki luas lahan tanaman sagu seluas 45.000 ha dimana sekitar 20.000 ha dikelola secara semi intensif. Potensi limbah perkebunan sagu tersebut selama ini kurang dimanfaatkan dengan baik, sedangkan di Kepulauan Meranti terdapat populasi ternak sapi sebanyak 3.635 ekor (BPS Kabupaten Kepulauan Meranti 2013) yang tersebar pada tujuh kecamatan. Hingga saat ini, sumber pakan ternak sapi hanya dari rumput alam di sekitar lingkungan peternakan dengan kualitas nutrisi rendah dan terkadang pakan tambahannya hanya dedak tanpa perlakuan.

Limbah dari perkebunan sagu berupa pelepah dan daun sedangkan ampas sagu merupakan limbah pengolahan batang sagu menjadi tepung sagu. Ampas sagu merupakan limbah yang didapatkan pada proses pengolahan tepung sagu, dimana dalam proses tersebut diperoleh tepung dan ampas sagu dalam perbandingan 1:6 (Rumalatu 1981). Proses pengolahan sagu menghasilkan limbah ikutan berupa kulit batang sekitar 17-25\% dan ampas sagu 75-83\% (McClatchey et al. 2006). Ampas sagu dapat dimanfaatkan sebagai campuran substrat biogas karena banyak mengandung bahan organik terutama unsur karbon dan pakan ternak bila diolah dengan baik (Lay \& Patrik 2010). Sementara selama ini ampas sagu terbuang percuma dan mencemari lingkungan perairan di sekitar Kabupaten Kepulauan Meranti yang diindikasikan keruhnya perairan di sekitar wilayah tersebut. Berdasarkan data Disperindag terdapat 47 unit pabrik pengolahan sagu yang tersebar di berbagai lokasi di Kepulauan Meranti. Umumnya pabrik sagu ini berada di kawasan bibir sungai dan sebagian besar pabrik sagu belum memiliki Rencana Pengelolaan Limbah (RPL). Ada kecenderungan pabrik sagu membuang limbahnya ke sungai. Dampak yang terjadi adalah perubahan parameter di perairan sekitar kawasan pembuangan limbah, baik dari sisi warna dan rasa. Ini merupakan indikasi awal terjadinya pencemaran perairan. Limbah itu dihasilkan dari kulit (uyung) sagu yang sudah dikupas dan limbah padat sagu (ampas) yang dihasilkan dari proses pengolahan sagu atau dalam bahasa setempat sering disebut repu. Selama ini puluhan ton limbah padat ini dibuang begitu saja oleh para pengusaha industri sagu.

Hasil penelitian menunjukkan bahwa daun sagu mempunyai kandungan BK 45,08\%; PK 4,73\%; LK 0,50\%; SK 29,00\%; Abu 9,00\%; BETN 56,77\%; NDF 80,39\%; dan ADF 70,00\% (Laboratorium Ilmu Nutrisi dan Kimia Fakultas Pertanian dan Peternakan UIN, 2014). Sedangkan ampas sagu memiliki kandungan bahan kering 54,03\%; GE 3,912 $\mathrm{kkal} / \mathrm{kg}$; BO 48,75\%; PK 5,02\%; NDF 67,78\% dan ADF 43,47\% (Laboratorium Ilmu Nutrisi dan Kimia Fakultas Pertanian dan Peternakan UIN 2014). Data nutrisi tersebut menunjukkan bahwa limbah perkebunan sagu dan limbah pengolahan tepung sagu memiliki potensi untuk dijadikan sebagai bahan pakan ternak sapi. Nuraini et al. (2005) melaporkan bahwa ampas sagu berupa serat-serat empelur diperoleh dari pemarutan dan pemerasan isi batang sagu dalam pengolahan batang sagu menjadi tepung sagu. Ampas sagu dapat menjadi alternatif bahan pakan sumber energi karena mengandung bahan ekstrak tanpa nitrogen (BETN) yang tinggi yaitu 76,51\%. Namun kurang baik bila digunakan sebagai pakan tunggal karena memiliki kandungan protein kasar rendah berdasarkan bahan kering. Untuk memanfaatkannya sebagai pakan ternak perlu difermentasikan untuk memperbaiki nilai nutrisi sehingga dapat diberikan sebagai pakan tunggal ataupun sebagai bahan campuran dalam pakan komplit. Tujuan penelitian ini adalah untuk mengetahui pemanfaatan limbah perkebunan sagu dan limbah pengolahan 
tepung sagu yang difermentasi sebagai pakan dan penggunaan limbah sagu fermentasi pada ternak sapi.

\section{MATERI DAN METODE}

\section{Waktu penelitian}

Kegiatan penelitian berlangsung dari bulan Juli-Oktober 2016 di Desa Maini Darul Aman Kecamatan Tebing Tinggi Barat Kabupaten Kepulauan Meranti.

\section{Metoda penelitian}

Dalam penelitian ini digunakan 20 ekor ternak sapi Bali jantan umur 1,5-2 tahun milik 10 orang petani koperator. Rata-rata berat badan awal ternak sapi perlakuan adalah $200 \pm 0,15 \mathrm{~kg}$. Bahan yang digunakan meliputi daun dan pelepah sagu yang telah dicacah, ampas sagu, probion, dedak, urea dan molases. Rancangan yang digunakan yaitu rancangan acak lengkap terdiri dari 4 perlakuan dan setiap perlakuan diulang sebanyak lima kali. Pakan komplit disusun dari bahan yaitu $60 \%$ cacahan pelepah dan daun sagu, $30 \%$ ampas sagu, $5,75 \%$ dedak, $0,25 \%$ urea, 3\% molases dan $0,1 \%$ garam. Sedangkan probion ditambahkan sebanyak $0,5 \%$ dari total bahan pakan. Seluruh bahan dicampur kemudian difermentasi secara anaerob selama 21 hari. Selanjutnya pakan komplit tersebut diberikan pada ternak sapi 3,5\% bobot badan berdasarkan kering sesuai dengan perlakuan sebagai berikut:
A : $100 \%$ rumput alam $+0 \%$ pakan fermentasi + dedak (kontrol)
B : $75 \%$ rumput alam $+25 \%$ pakan fermentasi + dedak
C : $50 \%$ rumput alam $+50 \%$ pakan fermentasi + dedak
D : $25 \%$ rumput alam $+75 \%$ pakan fermentasi + dedak

Ternak yang digunakan dalam penelitian ini sebelumnya diberi obat anti cacing dan vitamin terlebih untuk membuat kondisi ternak sehat sebelum masa adaptasi perlakuan. Ternak kemudian diberi waktu 14 hari untuk beradaptasi terhadap pakan perlakuan sebelum masa pengukuran dilakukan.

\section{Peubah yang diukur}

Peubah yang diukur adalah pertambahan berat badan harian (PBBH) diukur per dua minggu, konsumsi pakan setiap hari, kecernaan pakan perlakuan meliputi kecernaan bahan kering dan kecernaan bahan organik. Pengukuran lingkar dada dilakukan untuk mengetahui pertambahan bobot badan dilakukan menggunakan pita ukur dan kemudian ditabulasikan sesuai tabel rumus pendugaan berat badan menurut Schoorl. Pengukuran dilakukan per dua minggu selama empat bulan pada pagi hari sebelum ternak diberi pakan. Jumlah pakan dan sisanya ditimbang setiap hari untuk menghitung konsumsi pakan harian. Kandungan bahan kering pakan dan sisa pakan diketahui dengan cara mengambil sampel pakan dan sampel sisa pakan sebanyak $500 \mathrm{~g}$ untuk hijauan dan $100 \mathrm{~g}$ untuk pakan konsentrat. Sampel tersebut kemudian dimasukan ke dalam oven $105^{\circ} \mathrm{C}$ selama sehari semalam dan ditimbang keesokan harinya. Konsumsi pakan harian dihitung dengan menggunakan rumus:

Konsumsi pakan $(\mathrm{kg})$ = Pakan yang diberikan $(\mathrm{kg})$ - Sisa pakan $(\mathrm{kg})$

Kandungan bahan kering pakan $(\%)=\frac{\text { Sampel segar }- \text { Sampel kering }}{\text { Sampel segar }} \times 100 \%$ 
Sedangkan kecernaan bahan kering dihitung dengan menggunakan rumus sebagai berikut:

Kecernaan bahan kering $(\%)=\frac{\text { Bahan kering pakan yang dikonsumsi }- \text { Bahan kering feses }}{} \times 100 \%$ Bahan kering pakan yang dikonsumsi

Koleksi feses dilakukan dengan cara koleksi total yaitu feses total harian dari setiap ternak dikumpulkan dan ditimbang sebelum pemberian pakan pagi. $10 \%$ sampel diambil dan dikeringkan untuk persiapan analisis kecernaan.

\section{Analisis data}

Data konsumsi pakan, pertambahan berat badan harian serta kecernaan bahan kering pakan dianalisis menggunakan analysis of variance (ANOVA) dan apabila ditemukan perbedaan antara perlakuan maka dilanjutkan dengan uji beda nyata terkecil.

\section{HASIL DAN PEMBAHASAN}

\section{Potensi ampas sagu sebagai pakan}

Pencemaran lingkungan perairan akibat buangan ampas sagu hasil pencucian dalam pengolahan industri tepung sagu menjadi perhatian serius bagi Pemerintah Kabupaten Kepulauan Meranti (Gambar 1). Selama ini ampas sagu menjadi limbah atau bagian yang tidak dimanfaatkan oleh pihak perusahaan pengolahan sagu ternyata bernilai ekonomis tinggi, namun harus dikelola dengan melakukan inovasi. Penggunaan ampas sagu dalam pakan komplit sebesar 30\% merupakan salah satu inovasi untuk meningkatkan nilai limbah menjadi ekonomis serta mengurangi tingkat pencemaran hingga 80-90\%.

Produksi limbah sagu yang dihasilkan pada tahun 2016 tercatat sebanyak 2.640 .000 ton dalam bentuk basah (kadar air 40\%). Bila diasumsikan penggunaan ampas sagu $30 \%$ dalam pakan komplit per ekor per tahun sebanyak 1.095 ton, maka potensi ampas sagu mampu mendukung kebutuhan pakan untuk 2.411 ekor sapi per tahun.

Apabila angka perkiraan penggunaan ampas sagu tersebut dilakukan di seluruh wilayah Kabupaten Kepulauan Meranti, terdapat potensi pengembangan ternak sapi berbasis sagu sebesar 66,33\% dari populasi yang ada saat ini (3.636 ekor). Kondisi demikian dapat terwujud dengan adanya kebijakan dari Pemerintah Kabupaten Bengkalis untuk melakukan program pengembangan ternak sapi berbasis limbah sagu.
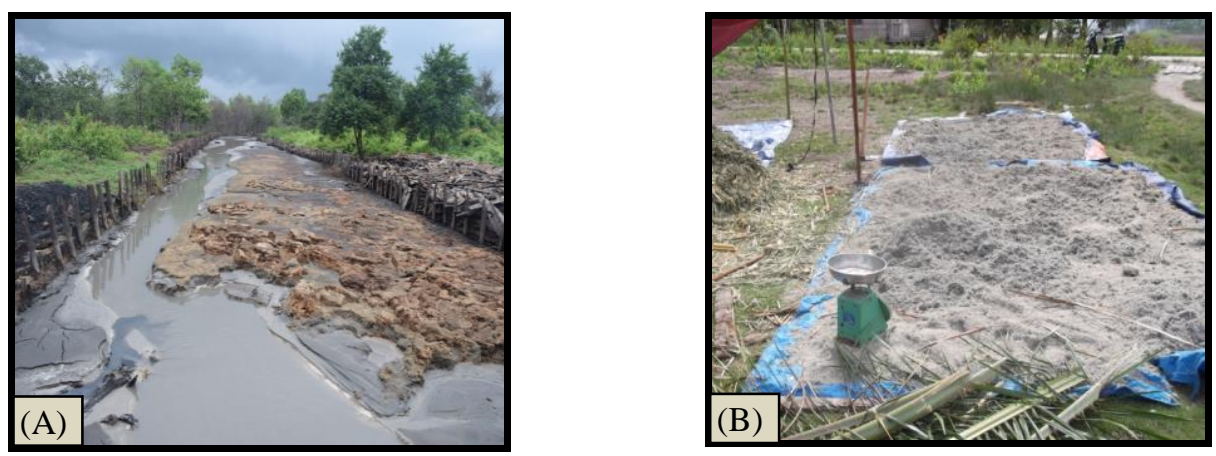

(A): Ampas sagu di lapangan; (B): Ampas sagu bahan pakan komplit

Gambar 1. Ampas sagu di lokasi penelitian 


\section{bahan kering dan pertambahan berat badan harian sapi}

Konsumsi bahan kering (BK), pertambahan berat badan harian (PBBH) dan kecernaan bahan kering (KCBK) pakan komplit limbah sagu fermentasi disajikan pada Tabel 1 berikut ini.

Dari hasil Anova menunjukkan bahwa perlakuan pakan komplit yang diberikan tidak berpengaruh $(\mathrm{P}>0,05)$ terhadap konsumsi $\mathrm{BK}$ dan $\mathrm{PBBH}$ sapi Bali pada masing-masing perlakuan. Sementara perlakuan pakan komplit memberikan pengaruh yang sangat nyata $(\mathrm{P}<0,01)$ terhadap KCBK pakan. Pemberian pakan komplit hingga $75 \%$ tidak memperlihatkan perbedaan dengan perlakuan lainnya untuk peubah konsumsi BK maupun PBBH namun memiliki KCBK paling rendah dibanding perlakuan lainnya. Kondisi ini menunjukkan bahwa pakan komplit berbahan dasar limbah sagu fermentasi dapat diberikan pada ternak sapi hingga 50\% dari tingkat kebutuhan dan masih memberikan respon pertumbuhan yang baik. Dengan demikian ketergantungan pola pemeliharaan ternak sapi yang selama ini berbasis pakan rumput alam saja dapat diganti dengan memanfaatkan limbah sagu yang potensinya sangat besar.

Konsumsi bahan kering ransum yang relatif sama pada semua perlakuan diduga karena kualitas pakan yang diberikan pada sapi relatif sama dimana kandungan nutrien terutama protein dan energi pakan perlakuan sama. Meskipun pakan fermentasi memiliki aroma yang lebih wangi dan umumnya lebih disukai ternak dibanding pakan non fermentasi tetapi hal tersebut belum mampu meningkatkan konsumsi BK pakan perlakuan. Akan tetapi bila dibandingkan dengan kontrol dapat dinyatakan bahwa tidak terdapat penurunan konsumsi BK seiiring dengan penurunan jumlah pemberian rumput lapangan.

Tabel 1. Konsumsi BK pakan, PBBH sapi dan KCBK pakan

\begin{tabular}{lcccc}
\hline \hline \multirow{2}{*}{ Peubah } & \multicolumn{4}{c}{ Perlakuan } \\
\cline { 2 - 5 } & $\mathrm{A}$ & $\mathrm{B}$ & $\mathrm{C}$ & $\mathrm{D}$ \\
\hline Konsumsi BK (kg/hari) & $7,57 \pm 0,34$ & $7,95 \pm 0,47$ & $8,37 \pm 0,29$ & $8,72 \pm 0,16$ \\
PBBH (kg/hari) & $0,542 \pm 0,11$ & $0,540 \pm 0,02$ & $0,58 \pm 0,04$ & $0,47 \pm 0,05$ \\
KCBK (\%) & $66,21^{\mathrm{c}} \pm 1,44$ & $63,70^{\mathrm{b}} \pm 1,27$ & $67,91^{\mathrm{d}} \pm 1,11$ & $57,44^{\mathrm{a}} \pm 4,00$ \\
\hline
\end{tabular}

Superskrip yang berbeda pada baris yang sama memperlihatkan perbedaan yang sangat nyata $(\mathrm{P}<0,01)$; A: Perlakuan kontrol; B: Perlakuan 25\% pakan fermentasi; C: Perlakuan 50\% pakan fermentasi; D: Perlakuan 75\% pakan fermentasi; KCBK: Kecernaan bahan kering; PBBH: Pertambahan berat badan harian

Hal tersebut mungkin disebabkan oleh sifat fisik dan kimia pakan ampas sagu fermentasi terolah lebih baik sehingga disukai oleh ternak. Selain itu kondisi ini juga sangat dipengaruhi oleh kualitas nutrisi pakan fermentasi yang dihasilkan, khususnya selulosa yang mengalami peningkatan. Parakkasi (1999) menyatakan bahwa faktor-faktor yang mempengaruhi konsumsi bahan pakan antara lain sifat fisik dan kimia pakan. Konsumsi pakan sama dengan perlakuan kontrol menunjukkan bahwa penggunaan pelepah dan sagu serta ampas sagu yang difermentasi masih dapat dikonsumsi ternak sapi dengan baik. Padahal selama ini potensi pakan yang berasal dari limbah perkebunan dan industri sagu terbuang percuma dan mencemari lingkungan.

Konsumsi bahan kering pakan pada penelitian ini setara dengan 5-5,6\% dari bobot badan. Nilai ini termasuk tinggi untuk nilai konsumsi BK bagi ternak sapi. Hal ini berarti tingkat palatabilitas pakan pada semua perlakuan tanpa fermentasi maupun dengan fermentasi sama baiknya. Konsumsi BK tersebut menunjukkan bahwa kebutuhan untuk hidup pokok dan kebutuhan untuk produksi ternak sapi sudah terpenuhi dengan baik atau 
dapat dinyatakan limbah sagu mempunyai potensi sebagai sumber pakan ternak sapi yang bagus.

Penambahan pakan fermentasi memberikan pengaruh yang sangat nyata terhadap kecernaan BK hingga tingkat penambahan 50\% pakan fermentasi yaitu sebesar $67,91 \%$, namun pada tingkat penambahan $75 \%$ terjadi penurunan kecernaan BK. Hal ini diduga bahwa pakan fermentasi masih dapat dikonsumsi dan dicerna lebih baik oleh ternak ruminansia hingga batasan jumlah tertentu. Kecernaan ransum dipengaruhi oleh komposisi pakan, kandungan nutrien serta proses pencernaan di dalam rumen dan saluran pascarumen (Beever \& Mould 2000). Sementara Arbi et al. (1977) menyatakan bahwa faktor-faktor yang mempengaruhi kecernaan antara lain konsumsi BK, kandungan zat-zat makanan dan laju makanan dalam saluran pencernaan.

PBBH sapi pada semua perlakuan berkisar antara $0,47-0,58 \mathrm{~kg} /$ hari dihasilkan oleh tingkat konsumsi pakan yang tidak berbeda. Nilai konsumsi pakan yang relatif sama juga akan mempengaruhi PBBH sapi yang menjadi sama antara perlakuan. Pertambahan bobot badan adalah akumulasi respon ternak terhadap konsumsi pakan, kecernaan bahan kering pakan, fermentasi, metabolisme dan penyerapan nutrien. Apabila dicermati pada perlakuan D yaitu penggunaan pakan komplit sagu fermentasi hingga $75 \%$ masih memberikan respon PBBH yang sama. Hal tersebut sesuai dengan yang dilaporkan oleh Pantjawidjaja et al. (1984) bahwa substitusi rumput lapangan dengan ampas sagu sampai pada level $45 \%$ dengan urea 3\% dari bahan kering ampas sagu tidak memperlihatkan perbedaan yang nyata dalam efisiensi penggunaan makanan dan pertambahan bobot badan sapi peranakan ongole, sedangkan menurut Nurkurnia (1989) penggunaan 40\% ampas sagu dalam ransum tidak mempengaruhi produksi volatile fatty acid (VFA) total atau parsial, imbangan asetat/propionat dan produksi $\mathrm{NH}_{3}$. Sementara hasil ini berbeda dengan yang dilaporkan Nanda (2011) bahwa sapi Bali yang mendapat ransum silase daun pelepah kelapa sawit sebagai substitusi rumput gajah justru mengalami penurunan bobot badan sebesar 40 $\mathrm{g} / \mathrm{hari}$.

\section{KESIMPULAN}

Limbah perkebunan dan hasil ikutan pengolahan tepung sagu dapat dijadikan sebagai pakan komplit fermentasi yang menghasilkan $\mathrm{PBBH}$ sapi Bali yang sama hingga pemberian $75 \%$. Dengan potensi ampas sagu sebanyak 2.640 .000 ton/tahun mampu mencukupi kebutuhan 2.411 ekor sapi/tahun.

\section{DAFTAR PUSTAKA}

Arbi N, Rivai M, Syarif A, Anwar S, Anam B. 1977. Produksi ternak sapi potong. Padang (Indonesia): Universitas Andalas.

BPS Riau. 2013. Riau dalam angka. Pekanbaru (Indonesia): Badan Pusat Statistik Provinsi Riau.

BPS Kabupaten Kepulauan Meranti. 2013. Sensus pertanian 2013. Selat Panjang (Indonesia): Badan Pusat Statistik Provinsi Riau.

Beever DE, Mould FL. 2000. Forage evaluation for efficient ruminant livestock production. London (Indonesia): CABI Publishing.

Lay AF, Tondak, Patrik M. 2010. Optimalisasi pengolahan sagu (Metroxylon sp) menjadi biofuel. Warta Penelitian dan Pengembangan Tanaman.

McClatchey WM, Harley I, Craig ER. 2006. Metroxylon Spp. London (UK): Ecology Papers Inc. 
Nanda DD. 2011. Konsumsi ransum dan pertambahan bobot badan sapi bali yang diberi ransum silase daun pelepah kelapa sawit sebagai substitusi rumput Gajah [Skripsi]. Pekanbaru (Indonesia): UIN Suska Riau.

Nurkurnia E. 1989. Hasil fermentasi rumen kambing Kacang betina dengan pemberian beberapa tingkat ampas sagu (Metroxylon sp) dalam ransum [Skripsi]. Bogor (Indonesia): Institut Pertanian Bogor.

Nuraini HY. Abbas, Rizal, Marlinda Y. 2005. Pemanfaatan ampas sagu fermentasi kaya $\beta$-karoten dalam ransum terhadap produksi dan kualitas telur ayam ras. J Ilmiah Ilmu-ilmu Peternakan Jambi. 8:55-59.

Pantjawidjaja, Pongsapan SP, Tandilinting FK.1984. penggunaan berbagai tingkat ampas sagu dalam ransum sapi Peranakan Ongole yang sedang tumbuh. Ilmu Peternakan. 1:163-166.

Parakkasi A. 1995. Ilmu nutrisi dan makanan ternak ruminan. Jakarta (Indonesia): UI Press.

Rumalatu FJ. 1981. Distribusi dan potensi pati beberapa sagu (Metroxylon sp) di daerah Seram Barat [Skripsi]. Bogor (Indonesia): Institut Pertanian Bogor.

\section{DISKUSI}

\section{Pertanyaan}

1. Berapa jumlah penambahan dedak pada pakan?

2. Berapa kapasitas pabrik sagu yang ada di lokasi?

3. Saran terkait PBBH, dikarenakan pemberian tidak ditimbang, cukup hanya menampilkan konsumsi pakannya saja?

\section{Jawaban}

1. Pemberian dedak dibatasi berdasarkan kandungan protein.

2. Kapasitas ampas sagu sebanyak 40 batang perhari.

3. Fermentasi mempengaruhi konsumsi pakan dan pertambahan bobot badan. 